\title{
URGENSI PROTEKSI PEMERINTAH TERHADAP USAHA KECIL DAN MENENGAH (studi kasus di Desa Pledokan Kecamatan Sumowono Kabupaten Semarang Provinsi Jawa Tengah)
}

\author{
Munadi \\ Program Studi Ilmu Politik - Universitas Sains Al-Qur'an
}

\begin{abstract}
Abstrak
Usaha Kecil dan Menengah (UKM) di Indonesia memiliki potensi laten atau tersembunyi yang sangat besar untuk bisa dikembangkan lebih jauh lagi. Berkaca dari sejarah, UKM menjadi salah satu sektor yang mampu bertahan dari deraan krisis ekonomi 1998 yang pernah melanda Indonesia. Ketika banyak perusahaan besar gulung tikar, UKM justru semakin banyak bermunculan. UKM bisa ikut mendorong pertumbuhan potensi ini dengan menyediakan pembiayaan yang diperlukan. Selama ini pinjaman yang diberikan oleh Bank, misalnya, kepada UKM cukup besar. Para pelaku usaha juga tidak memiliki kredit macet yang besar perputaran uang bisa terus berjalan dengan baik. Metode penelitian yang digunakan dalam riset ini adalah deskriptif kualitatif yakni data yang diperoleh dari hasil wawancara dan pengamatan. Sedangkan metode pengumpulan data yang digunakan dalam penelitian ini adalah wawancara, observasi dan dokumentasi.Hasil penelitian yang dilakukan terhadap UKM di Desa Pledokan Kecamatan Sumowono Kabupaten Semarang ini menunjukkan bahwa Pemerintah perlu meningkatkan perannya dalam memberdayakan UKM disamping mengembangkan kemitraan usaha yang saling menguntungkan antara pengusaha besar dengan pengusaha kecil, dan meningkatkan kualitas Sumber Daya Manusianya. Pengembangan terhadap sektor swasta merupakan suatu hal yang tidak diragukan lagi perlu untuk dilakukan. Pemerintah pada intinya memiliki kewajiban untuk turut melindungi UKM dengan memecahkan tiga hal masalah klasik yang kerap kali menerpa mereka, yakni akses pasar, modal, dan teknologi yang selama ini kerap menjadi pembicaraan di seminar atau konferensi. Perlu disadari, UKM berada dalam suatu lingkungan yang kompleks dan dinamis. Jadi, upaya mengembangkan UKM tidak banyak berarti bila tidak mempertimbangkan pembangunan (khususnya ekonomi) lebih luas. Konsep pembangunan yang dilaksanakan akan membentuk 'aturan main' bagi pelaku usaha (termasuk UKM) sehingga upaya pengembangan UKM tidak hanya bisa dilaksanakan secara parsial, melainkan harus terintegrasi dengan pembangunan ekonomi nasional dan dilaksanakan secara berkesinambungan.
\end{abstract}

Kata Kunci : Urgensi, Proteksi, UKM (Usaha Kecil dan Menengah) 


\section{A. PENDAHULUAN}

Di era globalisasi internasional dimana setiap negara tidak akan terhindar dari perdagangan bebas (Free Trade), karena seluruh negara dapat melakukan aktifitas ekspor (memasukkan) produknya ke suatu negara tujuan, kemudian sebaliknhya negara tersebut juga dapat dijadikan sasaran dimasukinya produk-produk dari negara lain. Hal ini yang sering disebut dengan perdagangan luar negeri. Aktifitas perdagangan luar negeri ini dapat berdampak baik dan juga berdampak buruk bagi sutu negara. Dampak baik dari melakukan perdagangan luar negeri ini karena setiap negara tidak dapat menghasilkan semua barang-barang yang dibutuhkannya. Misalnya negara-negara maju memerlukan karet alam tetapi barang tersebut tidak dapat dihasilkan di neagara-negara mereka. Maka mereka terpaksa mengimpor barang-barang tersebut dari negara-nefara di Asia Tenggara, terutama di Indonesia, Thailand dan Malaysia, sebaliknya negara-negara di Asia Tenggara belum dapat memproduksi sendiri beberapa industri modern seperti pesawat terbang, dan kapal pengangkut minyak . Maka negara-negara tersebut harus mengimpor dari negara maju (Sadono, 1994).

Dampak buruk yang kemungkinan terjadi pada perdagangan luar negeri ini diantaranya semakin terjepitnya produk-produk domestik yang kurang kompetitif dengan barang-barang dari luar negeri yang jauh lebih kompetitif dan dengan harga terjangkau. Apabila ini yang terjadi, maka produk lokal atau domestik akan merugi dan tidak dikonsumsi oleh konsumen dalam negerinya sehingga berakibat tidak berproduksinya produk domestik alias pengusaha (produsen lokal) akan dapat mengalami kebangkrutan. Efek ini semua menimbulkan gejolak sosial yang cukup serius mulai halangnya pekerjaan produsen hingga pemberhentian para pekerja yang mengakibatkan timbulnya pengangguran.

Survey secara umum, perkembangan terakhir sampai awal 1990-an telah mempercepat momentum globalisasi pasar keuangan hingga akhir abad yang lalu. Globalisasi telah mengubah pola hubungan finansial, proses produksi, perdagangan, tekhnologi informasi, dan hubungan ekonomi lain yang pada gilirannya menimbulkan gejala menyatunya ekonomi semua bangsa. Kita hidup dalam dunia tanpa batas. (Interdependensi antar bangsa) (Kuncoro, 2006:5). Tetapi ditengah bergulirnya arus globalisasi, yang secara umum lebih menguntungkan negara kaya daripada negara sedang berkembang, UKM kita juga telah terkena imbasnya akibat terjadinya ketidak adilan global. Ini terutama berlangsung di sektor pertanian, dinegara-negara maju seperti Amerika Serikat misalnya, para petani mendapatkan subsidi dana secara besar-besaran dalam membiayai kegiatan usahanya. Petani kapas, tebu, kacang, kedelai dan jagung serta berbagai jenis roduk pertanian lainnya, karena mendapatkan subsidi dari pemerintahnya, maka mereka dapat menjual produknya dengan harga murah dipasaran dunia, sementara itu, produk pertanian dari luar tersebut dikenai pajak bea masuk yang tinggi. Sebagai akibatnya produk ekspor pertanian kita sulit bersaing dalam harga dengan

produk dinegara tersebut, sebaliknya produk mereka yang masuk kenegeri kita bisa tampil dengan harga lebih murah daripada harga produk lokal. Karena itu tidak mengherankan apabila UKM kita berada pada posisi yang sulit, karena tak mampu bersaing dengan harga produk asing dinegerinya sendiri.

Proses globalisasi melalui AFTA (Asean Free Trade Area) atau WTO (World Trade Organization) dan lain-lain hanya menguntungkan neagara maju dan malah menggilas UKM kita sendiri. 
UKM (Usaha Kecil dan Menengah) sebenarnya mempunyai peran yang strategis dalam pembangunan ekonomi nasional, oleh karena selain berperan dalam pertumbuhan eknomi dan penyerapan tenaga kerja juga berperan dalam pendistribusian hasil-hasil pembangunan. Dalam krisis ekonomi yang terjadi di negara kita sejak beberapa waktu yang lalu, dimana banyak usaha berskala besar yang mengalami stagnasi bahkan berhenti aktifitasnya, sektor UKM (Usaha Kecil dan Menengah) terbukti lebih tangguh dalam menghadapi krisis tersebut. Pengembangan UKM perlu mendapatkan perhatian yang besar baik dari pemerintah maupun masyarakat agar dapat berkembang lebih kompetitif bersama pelaku ekonomi lainnya. Kebijakan pemerintah kedepan perlu diupayakan lebih kondusif bagi tumbuh dan berkembangnya UKM. Pemerintah perlu meningkatkan perannya dalam memberdayakan UKM disamping mengembangkan kemitraan usaha yang saling menguntungkan antara pengusaha besar dengan pengusaha kecil, dan meningkatkan kualitas Sumber Daya Manusianya.

Pengembangan UKM ke depan, perlu menggabungkan keunggulan lokal (lingkungan internal) dan peluang pasar global, yang disinergikan dengan era otonomi daerah dan pasar bebas. Perlu berpikir dalam skala global dan bertindak lokal (think globaly and act locally) dalam mengambil kebijakan yang terkait dengan pengembangan UKM. UKM (Usaha Kecil dan Menengah) mempunyai peran yang cukup besar dalam pembangunan ekonomi nasional, hal ini terlihat dari kontribusinya terhadap Produk Domestik Bruto (PDB) Indonesia yang terus meningkat setiap tahunnya. Berdasarkan hasil survei dan perhitungan Badan Pusat Statistik (BPS), kontribusi UKM terhadap PDB (tanpa migas) pada Tahun 1997 tercatat sebesar 62,71 persen dan pada Tahun 2002 kontribusinya meningkat menjadi 63,89 persen. Perbandingan komposisi PDB menurut kelompok usaha pada Tahun 1997 dan 2003.

Kendati demikian, kondisi UKM tetap rawan karena keberpihakan bank yang rendah, pasar bebas yang mulai dibuka, serta terbatasnya kebijakan yang mendukung sektor usaha kecil. Sedangkan kontribusi usaha yang berskala besar pada Tahun 1997 hanya 37,29 persen dan pada Tahun 2002 turun lagi menjadi 36,11 persen. Jumlah unit UKM dalam 3 (tiga) tahun terakhir juga mengalami peningkatan rata-rata sebesar 9,5 persen tiap tahunnya. Pada Tahun 2002 tercatat sebanyak 38,7 juta dan pada Tahun 2004 sebanyak 42,4 juta unit usaha. Peningkatan jumlah unit usaha ini juga diikuti dengan kenaikan jumlah tenaga kerja disektor UKM. Pada Tahun 2004 jumlah pekerja di sektor UKM tercatat hampir 80 juta orang, dari jumlah tersebut sebanyak 70,3 juta diantaranya bekerja disektor usaha kecil dan sisanya disektor usaha menengah. Disadari akan begitu besarnya peran UKM dalam perekonomian nasional, maupun dalam penyerapan tenaga kerja dan pemerataan distribusi hasil-hasil pembangunan, maka pemerintah melalui Undang-undang No 5 tahun 1999, memberi batasan terhadap UKM yaitu untuk usaha kecil adalah usaha yang :

a. Memiliki kekayaan (aset) bersih 200 juta, tidak termasuk tanah dan bangunan tempat usaha,

b. Hasil penjualan tahunan (omzet) paling banyak 1 milyar,

c. Milik warga Indonesia,

d. Berdiri sendiri, bukan merupakan anak perusahaan atau cabang perusahaan

Dengan batasan tersebut, maka diharapkan peranan pemerintah maupun masyarakat perlu memberikan perhatian yang besar untuk mendorong pengembangannya. Pengembangan UKM melalui pendekatan pemberdayaan usaha, perlu memperhatikan aspek sosial dan budaya di masing-masing daerah, mengingat usaha kecil dan menengah 
pada umumnya tumbuh dari masyarakat secara langsung. Disamping itu upaya pengembangan UKM dengan mensinergikannya dengan industri besar melalui pola kemitraan, juga akan memperkuat struktur ekonomi baik nasional maupun daerah. Partisipasi pihak terkait atau stakeholders perlu terus ditumbuhkembangkan lainnya agar UKM betul-betul mampu berkiprah lebih besar lagi dalam perekonomian nasional.

UKM (Usaha Kecil dan Menengah) adalah kegiatan usaha yang dilakukan oleh orang perorangan atau kelompok yang bertujuan untuk mensejahterakan individu maupun kelompoknya. UKM (Usaha Kecil dan Menengah) yang ada di desa Pledokan antara lain sirup jahe alang alang, sirup alang-alang, sirup jahe, gula aren, kecap, dan bubuk kopi. Lokasi UKM (Usaha Kecil dan Menengah) yang kami datangi terletak di Dusun Pledokan. UKM tersebut sudah sesuai dengan potensi, SDA, serta SDM yang ada di daerah Desa Pledokan, terlihat dari bahan baku yang digunakan berasal dari hasil panen di daerah sekitar desa. Selain itu, pegawai yang membantu proses produksi merupakan warga Desa Pledokan itu sendiri.

UKM (Usaha Kecil dan Menengah) selain kegiatan di atas ada juga UKM (Usaha Kecil dan Menengah) berupa bubuk kopi yang dimiliki oleh Pak Waluyo dengan nama produk Pledokan Coffee Robusta. UKM ini sebenarnya telah berdiri sejak tahun 2001, akan tetapi dari tahun 2001 sampai dengan 2015 hanya memproduksi biji kopinya saja, baru pada tahun 2015 mulai dirintis usaha bubuk kopi. Tenaga kerja yang dimiliki sebanyak dua orang, bahan baku untuk memproduksi bubuk kopi adalah biji kopi yang diperoleh dari desanya sendiri dengan kapasitas $15 \mathrm{~kg} /$ bulan. Cakupan wilayah pemasaran yaitu Restoran di Semarang dan BPP Kecamatan Sumowono, jenis pemasaran yang dilakukan yaitu penjualan langsung.

UKM (Usaha Kecil dan Menengah) Gula Aren yang dimiliki oleh Pak Widarto turut serta dalam pengembangan UKM (Usaha Kecil dan Menengah). Tenaga kerja yang dimiliki sebanyak dua orang dengan 1 orang pria dan 1 wanita, bahan baku untuk memproduksi berupa gula aren yang didapat dari Desa Pledokan sendiri. Kapasitas produksi mencapai 15-20 per Liter. Cakupan wilayah pemasaran baru meliputi lingkup desa dengan jenis pemasaran yang dilakukan yaitu penjualan langsung.

UKM KWT (Kelompok Wanita Tani) Arum Sari diketuai oleh Ibu Yatimah dengan nama produk TAZAKKA. Adapun yang diproduksi antara lain Sirup Jahe, Sirup Jahe Alang-Alang, Gula Aren, Kecap, Akar alang-alang. Tenaga kerja yang dimiliki sebanyak 4 orang dengan 3 orang wanita dan 1 orang pria. Untuk sirup jahe bahan baku yang diperlukan Jahe dan Gula Aren yang diperoleh dari desa pledokan sendiri, kapasitas produksi rata-rata 40 botol per order. Cakupan wilayah pemasaran sudah meliputi lingkup kabupaten, jenis pemasaran yang dilakukan yaitu penjualan langsung. Untuk kecap bahan baku yang diperlukan antara lain kedelai hitam dan gula aren, untuk kedelai hitam menjadi kendala karena harus diperoleh dari luar kota yaitu Jogja dan Solo. Cakupan wilayah pemasaran sudah meliputi lingkup kabupaten dengan jenis pemasaran yang dilakukan yaitu penjualan langsung. Lalu produk sirup jahe alang-alang bahan baku yang diperlukan akar alang-alang, gula aren dan ramuan lain kapasitas produksi rata-rata 40 botol per order. Cakupan wilayah pemasaran sudah meliputi lingkup kabupaten, jenis pemasaran yang dilakukan yaitu penjualan langsung. 


\section{B. METODE PENELITIAN}

Metode penelitian yang digunakan dalam penelitian ini adalah penelitian kualitatif yaitu proses memahami masalah sosial atau manusia berdasarkan penciptaan gambaran secara holistik lengkap yang dibentuk dengan kata-kata, melaporkan pandangan informan secara terperinci dan disusun dalam latar ilmiah. Serta data yang dikumpulkan berupa kata-kata atau kalimat atau gambar atau tabel.

Pendekatan yang digunakan dalam penelitian ini adalah studi kasus. Menurut Muhajir analisis studi kasus menyangkut objek-objek seperti: laju perkembangan dalam arti kecendrungan, pola, dan juga ketidakteraturan dan penyimpangan, tingkat kedewasaan, dalam arti tampilan perilaku dan integrasinya, karakteristik pribadi, mempelajari masa lampaunya untuk membuat diagnosis dan mencari faktor penyebab, dan memprediksikan masa depannya, membuat prognosis berdasar asumsi stabilitas perkembangannya (Muhajir, 61: 2000).

Cara memperoleh data dalam penelitian ini digunakan purposive sampling dimana peneliti cenderung memilih informan yang dianggap mengetahui dan dapat dipercaya untuk menjadi sumber data namun demikian informan yang dipilih dapat menunjukan informan lain yang lebih tahu (snowball) maka pilihan informan dapat berkembang sesuai dengan kebutuhan dan kemantapan peneliti dalam memproleh data.

Metode dalam pengumpulan data dalam penelitian ini dengan cara wawancara mendalam dilakukan secara informal yang dapat dilakukan pada waktu atau konteks yang dianggap tepat guna mendapatkan data yang mempunyai kedalaman dan dapat dilakukan berkali-kali sesuai dengan keperluan peneliti.

Teknik ini dimaksudkan agar peneliti mampu mengeksplorasi data dari informan yang bersifat data, nilai, makna dan pemahaman yang belum terungkap, cara pengambilan informasi yang dilakukan dengan tanya jawab yang bersifat informal dengan informan.

Dokumentasi dapat berupa surat, memoranda, agenda, pengumuman-pengumuman, catatan rapat, proposal, progress report, laporan studi yang pernah dilakukan di tempat yang sama, kliping berita, dan juga artikel di media masa yang relevan. Dalam penelitian ini didokumentasikan data-data yang didapat juga dari agenda-agenda kegiatan masyarakat Desa Pledokan Kecamatan Sumowono Kabupaten Semarang.

Observasi dilakukan untuk memperoleh data melalui pengamatan terhadap fenomena sosial yang menjadi kajian dalam penelitian, observasi atau pengamatan langsung merupakan metode pengumpulan data dimana peneliti melakukan pengamatan secara langsung terhadap fenomena sosial yang terjadi di lokasi penelitian untuk mendapatkan data yang bersifat tindakan atau tingkah laku sehari-hari. Observasi atau pengamatan ini dimaksudkan sebagai pengumpulan data secara selektif. Menurut Lincoln dan Guba (1985 dalam Ruslan: 2004: 33) 


\section{Sumber dan Jenis Data}

\section{a. Sumber Data}

Dalam penelitian ini beberapa informan awal dipilih secara purposive atas dasar pertimbangan bahwa informan yang dipilih memang benar-benar memahami permasalahan yang akan diteliti, seperti ketua UKM (Usaha Kecil dan Menengah), Kepala Desa dan perangkatnya yang didalamnya sekretaris desa sampai kepada ketua RW dan RT di Desa Pledokan Kecamatan Sumowono Kabupaten Semarang serta masyarakat setempat yang terlibat dalam UKM (Usaha Kecil dan Menengah).

\section{b. Jenis Data}

1. Data Primer

Data primer adalah data yang diperoleh dari responden sebagai sumber utama yang dijadikan sasaran penelitian yakni, Kepala Desa Pledokan Kecamatan Sumowono Kabupaten Semarang perangkatnya, ketua RW, ketua RT, dan ketua UKM (Usaha Kecil Menengah).

2. Data Sekunder

Data sekunder adalah data yang diperoleh dari arsip-arsip atau dokumendokumen yang relevan dengan permasalahan penelitian untuk melengkapi dan memperjelas data primer. Data sekunder dapat berupa data penduduk masyarakat di Desa Pledokan Kecamatan Sumowono Kabupaten Semarang.

Teknik analisis yang digunakan dalam penelitian adalah melalui tahapan sebagai berikut: (1) Pengumpulan data; (2) Reduksi data; (3) Penyajian data; (4) Penarikan Kesimpulan/Verifikasi.

\section{HASIL PENELITIAN}

Pada umumnya permasalahan yang dihadapi oleh UKM (Usaha Kecil dan Menengah) di Desa Pledokan Kecamatan Sumowono Kabupaten Semarang, antara lain meliputi:

\section{a. Faktor Internal}

1. Kurangnya Permodalan

Permodalan merupakan faktor utama yang diperlukan untuk mengembangkan suatu unit usaha. Kurangnya permodalan UKM (Usaha Kecil dan Menengah), oleh karena pada umumnya usaha kecil dan menengah merupakan usaha perorangan atau perusahaan yang sifatnya tertutup, yang mengandalkan pada modal dari si pemilik yang jumlahnya sangat terbatas, sedangkan modal pinjaman dari bank atau lembaga keuangan lainnya sulit diperoleh, karena persyaratan secara administratif dan teknis yang diminta oleh bank tidak dapat dipenuhi.

2. Sumber Daya Manusia (SDM) yang Terbatas

Sebagian besar usaha kecil tumbuh secara tradisional dan merupakan usaha keluarga yang turun temurun. Keterbatasan SDM usaha kecil baik dari segi pendidikan formal maupun pengetahuan dan keterampilannya sangat berpengaruh terhadap manajemen pengelolaan usahanya, sehingga usaha tersebut sulit untuk berkembang dengan optimal. Disamping itu dengan keterbatasan SDM-nya, unit usaha tersebut relatif sulit untuk mengadopsi perkembangan teknologi baru untuk meningkatkan daya saing produk yang dihasilkannya. 
3. Lemahnya Jaringan Usaha dan Kemampuan Penetrasi Pasar Usaha kecil yang pada umumnya merupakan unit usaha keluarga, mempunyai jaringan usaha yang sangat terbatas dan kemampuan penetrasi pasar yang rendah, oleh karena produk yang dihasilkan jumlahnya sangat terbatas dan mempunyai kualitas yang kurang kompetitif. Berbeda dengan usaha besar yang telah mempunyai jaringan yang sudah solid serta didukung dengan teknologi yang dapat menjangkau internasional dan promosi yang baik.

\section{b. Faktor Eksternal}

1. Iklim Usaha Belum Sepenuhnya Kondusif

Kebijaksanaan Pemerintah untuk menumbuh kembangkan Usaha Kecil dan Menengah (UKM), Meskipun dari tahun ke tahun terus disempurnakan, namun dirasakan belum sepenuhnya kondusif. Hal ini terlihat antara lain masih terjadinya persaingan yang kurang sehat antara pengusaha-pengusaha kecil dengan pengusaha-pengusaha besar di Desa Pledokan Kecamatan Sumowono Kabupaten Semarang.

2. Terbatasnya Sarana dan Prasarana Usaha

Kurangnya informasi yang berhubungan dengan kemajuan ilmu pengetahuan dan teknologi, menyebabkan sarana dan prasarana yang mereka miliki juga tidak cepat berkembang dan kurang mendukung kemajuan usahanya sebagaimana yang diharapkan.

3. Implikasi Otonomi Daerah

Dengan berlakunya Undang-undang No. 22 Tahun 1999 tentang Otonomi Daerah, kewenangan daerah mempunyai otonomi untuk mengatur dan mengurus masyarakat setempat. Perubahan sistem ini akan mengalami implikasi terhadap pelaku bisnis kecil dan menengah berupa pungutan-pungutan baru yang dikenakan pada UKM (Usaha Kecil dan Menengah) di Desa Pledokan Kecamatan Sumowono Kabupaten Semarang. Jika kondisi ini tidak segera dibenahi maka akan menurunkan daya saing Usaha Kecil dan Menengah (UKM). Disamping itu semangat kedaerahan yang berlebihan, kadang menciptakan kondisi yang kurang menarik bagi pengusaha luar daerah untuk mengembangkan usahanya di daerah tersebut.

4. Implikasi Perdagangan Bebas

Sebagaimana diketahui bahwa AFTA yang mulai berlaku Tahun 2003 dan APEC Tahun 2020 yang berimplikasi luas terhadap usaha kecil dan menengah untuk bersaing dalam perdagangan bebas. Dalam hal ini, mau tidak mau UKM (Usaha Kecil dan Menengah) dituntut untuk melakukan proses produksi dengan produktif dan efisien, serta dapat menghasilkan produk yang sesuai dengan frekuensi pasar global dengan standar kualitas seperti isu kualitas (ISO 9000), isu lingkungan (ISO 14.000) dan isu Hak Asasi Manusia (HAM) serta isu ketenagakerjaan. Isu ini sering digunakan secara tidak fair oleh negara maju sebagai hambatan (Non Tariff Barrier for Trade). Untuk itu maka diharapkan UKM di Desa Pledokan Kecamatan Sumowono Kabupaten Semarang perlu mempersiapkan agar mampu bersaing baik secara keunggulan komparatif maupun keunggulan kompetitif yang berkelanjutan.

5. Sifat Produk Dengan Lifetime Pendek Sebagian besar produk industri kecil memiliki ciri atau karakteristik sebagai produk-produk fasion dan kerajinan dengan lifetime yang pendek. 


\section{Terbatasnya Akses Pasar}

Terbatasnya akses pasar akan menyebabkan produk yang dihasilkan tidak dapat dipasarkan secara kompetitif baik di pasar nasional maupun internasional.

Upaya Pemerintah untuk Pengembangan UKM dalam potensi sektor usaha kecil yang cukup besar dalam peranannya untuk memperkuat pembangunan ekonomi nasional dengan beberapa kelebihan dan keunggulan yang spesifik, mampu menggerakkan perekonomian di wilayah pedesaan, dapat menyerap tenaga kerja yang tidak harus memiliki tingkat pendidikan tertentu, mendukung dan meningkatkan nilai ekspor non migas, memanfaatkan kegiatan kredit sektor perbankan yang sudah dialokasikan untuk UKM atau UMKM (Kuncoro, 2007:87).

Pengembangan UKM (Usaha Kecil dan Menengah) pada hakekatnya merupakan tanggungjawab bersama antara pemerintah dan masyarakat. Dengan kata lain pemerintah dalam hal ini mutlak diperlukan intervensinya dalam membela dan membantu para pengusaha UKM (Usaha Kecil dan Menengah). Dengan mencermati permasalahan yang dihadapi oleh UKM, maka kedepan perlu diupayakan langkah-langkah sebagai berikut:

1. Penciptaan Iklim Usaha yang Kondusif Pemerintah perlu mengupayakan terciptanya iklim yang kondusif antara lain dengan mengusahakan ketenteraman dan keamanan berusaha serta penyederhanaan prosedur perijinan usaha, keringanan pajak dan sebagainya.

2. Bantuan Permodalan

Pemerintah perlu memperluas skim kredit khusus dengan syarat-syarat yang tidak memberatkan bagi UKM, untuk membantu peningkatan permodalannya, baik itu melalui sektor jasa finansial formal, sektor jasa finansial informal, skema penjaminan, leasing dan dana modal ventura.

Pembiayaan untuk UKM (Usaha Kecil dan Menengah) sebaiknya menggunakan LKM (Lembaga Keuangan Mikro) yang ada, maupun non bank. Lembaga Keuangan Mikro bank antara Lain: BRI (Bank Rakyat Indonesia) unit Desa dan BPR (Bank Perkreditan Rakyat). Sampai saat ini BRI memiliki sekitar 4.000 unit yang tersebar diseluruh Indonesia. Dari kedua LKM ini sudah tercatat sebanyak 8.500 unit yang melayani UKM. Untuk itu perlu mendorong pengembangan LKM . Beberapa hal yang harus dilakukan sekarang ini adalah bagaimana mendorong pengembangan LKM ini berjalan dengan baik, karena selama ini LKM non Koperasi memilki kesulitan dalam legitimasi operasionalnya.

3. Perlindungan Usaha

Jenis-jenis usaha tertentu, terutama jenis usaha tradisional yang merupakan usaha golongan ekonomi lemah, harus mendapatkan perlindungan dari pemerintah, baik itu melalui undangundang maupun peraturan pemerintah yang bermuara kepada saling menguntungkan (win-win solution).

Perlindungan pemerintah dapat dilihat dari banyaknya produk peraturan yang mengatur tentang UKM diantaranya : UU No. 9 Tahun 1995 tentang Usaha Kecil, PP No. 44 Tahun 1997 tentang Kemitraan, PP No. 32 Tahun 1998 tentang Pembinaan dan Pengembangan Usaha Kecil, Inpres No. 10 Tahun 1999 tentang Pemberdayaan Usaha Menengah, Keppres No. 127 Tahun 2001 tentang Bidang/Jenis Usaha Yang Dicadangkan Untuk Usaha Kecil dan Bidang/Jenis Usaha Yang Terbuka Untuk Usaha Menengah atau Besar Dengan Syarat Kemitraan, Keppres No. 56 Tahun 2002 tentang Restrukturisasi Kredit Usaha Kecil dan Menengah, Permenneg BUMN Per- 
05/MBU/2007 tentang Program Kemitraan Badan Usaha Milik Negara dengan Usaha Kecil dan Program Bina Lingkungan, Permenneg BUMN Per-05/MBU/2007 tentang Program Kemitraan Badan Usaha Milik Negara, Undang-undang No. 20 Tahun 2008 tentang Usaha Mikro, Kecil, dan Menengah.

Namun dalam praktek dan aplikasinya dilapangan peraturan yang diberikan pemerintah ini kurang optimal dalam operasionalnya, sehingga perlu adanya komitmen yang kuat dari pemerintah agar regulasi yang telah dibuat dapat benarbenar menguntungkan para kelompok UKM.

4. Pengembangan Kemitraan

Perlu dikembangkan kemitraan yang saling membantu antara UKM, atau antara UKM dengan pengusaha besar di dalam negeri maupun di luar negeri, untuk menghindarkan terjadinya monopoli dalam usaha. Disamping itu juga untuk memperluas pangsa pasar dan pengelolaan bisnis yang lebih efisien. Dengan demikian UKM akan mempunyai kekuatan dalam bersaing dengan pelaku bisnis lainnya, baik dari dalam maupun luar negeri.

Pola kemitraan antara UKM dan UB di Indonesia yang telah dibakukan, menurut UU No. 9 Tahun 1995 tentang Usaha Kecil dan PP No. 44 Tahun 1997 tentang kemitraan, terdiri atas 5 (lima) pola, yaitu : (1).Inti Plasma, (2).Subkontrak, (3).Dagang Umum, (4).Keagenan, dan (5).Waralaba.

Pola pertama, yaitu inti plasma merupakan hubungan kemitraan antara UKM dan UB sebagai inti membina dan mengembangkan UKM yang menjadi plasmanya dalam menyediakan lahan, penyediaan sarana produksi, pemberian bimbingan teknis manajemen usaha dan produksi, perolehan, penguasaan dan peningkatan teknologi yang diperlukan bagi peningkatan efisiensi dan produktivitas usaha. Dalam hal ini, UB mempunyai tanggung jawab sosial (corporate social responsibility) untuk membina dan mengembangkan UKM sebagai mitra usaha untuk jangka panjang.

Pola kedua, yaitu subkontrak merupakan hubungan kemitraan UKM dan UB, yang didalamnya UKM memproduksi komponen yang diperlukan oleh UB sebagai bagian dari produksinya. Subkontrak sebagai suatu sistem yang menggambarkan hubungan antara UB dan UKM, di mana UB sebagai perusahaan induk (parent firma) meminta kepada UKM selaku subkontraktor untuk mengerjakan seluruh atau sebagian pekerjaan (komponen) dengan tanggung jawab penuh pada perusahaan induk. Selain itu, dalam pola ini UB memberikan bantuan berupa kesempatan perolehan bahan baku, bimbingan dan kemampuan teknis produksi, penguasaan teknologi, dan pembiayaan.

Pola ketiga, yaitu dagang umum merupakan hubungan kemitraan UKM dan UB, yang di dalamnya UB memasarkan hasil produksi UKM atau UKM memasok kebutuhan yang diperlukan oleh UB sebagai mitranya. Dalam pola ini UB memasarkan produk atau menerima pasokan dari UKM untuk memenuhi kebutuhan yang diperlukan oleh UB.

Pola keempat, yaitu keagenan merupakan hubungan kemitraan antara UKM dan UB, yang di dalamnya UKM diberi hak khusus untuk memasarkan barang dan jasa UB sebagai mitranya. Pola keagenan merupakan hubungan kemitraan, di mana pihak prinsipal memproduksi atau memiliki sesuatu, sedangkan pihak lain (agen) bertindak sebagai pihak yang menjalankan bisnis tersebut dan menghubungkan produk yang bersangkutan langsung dengan pihak ketiga. 
Pola kelima, yaitu waralaba merupakan hubungan kemitraan, yang di dalamnya pemberi waralaba memberikan hak penggunaan lisensi, merek dagang, dan saluran distribusi perusahaannya kepada penerima waralaba dengan disertai bantuan bimbingan manajemen. Dalam pola ini UB yang bertindak sebagai pemberi waralaba menyediakan penjaminan yang diajukan oleh UKM sebagai penerima waralaba kepada pihak ketiga.

5. Pelatihan

Pemerintah perlu meningkatkan pelatihan bagi UKM baik dalam aspek kewiraswastaan, manajemen, administrasi dan pengetahuan serta keterampilannya dalam pengembangan usahanya. Disamping itu juga perlu diberi kesempatan untuk menerapkan hasil pelatihan di lapangan untuk mempraktekkan teori melaluipengembangan kemitraan rintisan.

6. Membentuk Lembaga Khusus

Perlu dibangun suatu lembaga yang khusus bertanggung jawab dalam mengkoordinasikan semua kegiatan yang berkaitan dengan upaya penumbuhkembangan UKM dan juga berfungsi untuk mencari solusi dalam rangkamengatasi permasalahan baik internal maupun eksternal yang dihadapi oleh UKM.

7. Memantapkan Asosiasi

Asosiasi yang telah ada perlu diperkuat, untuk meningkatkan perannya antara lain dalam pengembangan jaringan informasi usaha yang sangat dibutuhkan untuk pengembangan usaha bagi anggotanya.

8. Mengembangkan Promosi

Guna lebih mempercepat proses kemitraan antara UKM dengan usaha besar diperlukan media khusus dalam upaya mempromosikan produk-produk yang dihasilkan. Disamping itu perlu juga diadakan talk show antara asosiasi dengan mitra usahanya.

9. Mengembangkan Kerjasama yang Setara Perlu adanya kerjasama atau koordinasi yang serasi antara pemerintah dengan dunia usaha (UKM) untuk menginventarisir berbagai isu-isu mutakhir yang terkait dengan perkembangan usaha.

\section{SIMPULAN}

UKM (Usaha Kecil dan Menengah) di Desa Pledokan Kecamatan Sumowono Kabupaten Semarang mempunyai peran yang strategis dalam pembangunan ekonomi nasional, oleh karena selain berperan dalam pertumbuhan ekonomi dan penyerapan tenaga kerja juga berperan dalam pendistribusian hasil-hasil pembangunan. Dalam krisis ekonomi yang terjadi di negara kita sejak beberapa waktu yang lalu, dimana banyak usaha berskala besar yang mengalami stagnasi bahkan berhenti aktifitasnya, sektor UKM (Usaha Kecil dan Menengah) terbukti lebih tangguh dalam menghadapi krisis tersebut. Mengingat pengalaman yang telah dihadapi oleh Indonesia selama krisis, kiranya tidak berlebihan apabila pengembangan sektor swasta difokuskan pada UKM, terlebih lagi unit usaha ini seringkali terabaikan hanya karena hasil produksinya dalam skala kecil dan belum mampu bersaing dengan unit usaha lainnya.

Pengembangan UKM perlu mendapatkan perhatian yang besar baik dari pemerintah maupun masyarakat agar dapat berkembang lebih kompetitif bersama pelaku ekonomi lainnya. Kebijakan pemerintah ke depan perlu diupayakan lebih kondusif bagi tumbuh dan berkembangnya UKM. Pemerintah perlu meningkatkan perannya dalam memberdayakan 
UKM disamping mengembangkan kemitraan usaha yang saling menguntungkan antara pengusaha besar dengan pengusaha kecil, dan meningkatkan kualitas Sumber Daya Manusianya.

Pengembangan terhadap sektor swasta merupakan suatu hal yang tidak diragukan lagi perlu untuk dilakukan. UKM memiliki peran penting dalam pengembangan usaha di Indonesia. UKM juga merupakan cikal bakal dari tumbuhnya usaha besar. "Hampir semua usaha besar berawal dari UKM. UKM (Usaha kecil menengah) harus terus ditingkatkan (up grade) dan aktif agar dapat maju dan bersaing dengan perusahaan besar. Jika tidak, UKM di Indonesia yang merupakan jantung perekonomian Indonesia tidak akan bisa maju dan berkembang. Satu hal yang perlu diingat dalam pengembangan UKM adalah bahwa langkah ini tidak semata-mata merupakan langkah yang harus diambil oleh Pemerintah dan hanya menjadi tanggung jawab Pemerintah. Pihak UKM sendiri sebagai pihak yang dikembangkan, dapat mengayunkan langkah bersama-sama dengan Pemerintah. Selain Pemerintah dan UKM, peran dari sektor Perbankan juga sangat penting terkait dengan segala hal mengenai pendanaan, terutama dari sisi pemberian pinjaman atau penetapan kebijakan perbankan. Lebih jauh lagi, terkait dengan ketersediaan dana atau modal, peran dari para investor baik itu dari dalam maupun luar negeri, tidak dapat pula kita kesampingkan.

Pemerintah pada intinya memiliki kewajiban untuk turut memecahkan tiga hal masalah klasik yang kerap kali menerpa UKM, yakni akses pasar, modal, dan teknologi yang selama ini kerap menjadi pembicaraan di seminar atau konferensi. Secara keseluruhan, terdapat beberapa hal yang harus diperhatikan dalam melakukan pengembangan terhadap unit usaha UKM, antara lain kondisi kerja, promosi usaha baru, akses informasi, akses pembiayaan, akses pasar, peningkatan kualitas produk dan SDM, ketersediaan layanan pengembangan usaha, pengembangan cluster, jaringan bisnis, dan kompetisi.

Perlu disadari, UKM berada dalam suatu lingkungan yang kompleks dan dinamis. Jadi, upaya mengembangkan UKM tidak banyak berarti bila tidak mempertimbangkan pembangunan (khususnya ekonomi) lebih luas. Konsep pembangunan yang dilaksanakan akan membentuk 'aturan main' bagi pelaku usaha (termasuk UKM) sehingga upaya pengembangan UKM tidak hanya bisa dilaksanakan secara parsial, melainkan harus terintegrasi dengan pembangunan ekonomi nasional dan dilaksanakan secara berkesinambungan. Kebijakan ekonomi (terutama pengembangan dunia usaha) yang ditempuh selama ini belum menjadikan ikatan kuat bagi terciptanya keterkaitan antara usaha besar dan UKM.

\section{DAFTAR REFERENSI}

Akatiga. Laporan Studi Dinamika dan Dampak Krisis Bagi Usaha Kecil. Bandung: Akatiga, 2000.

Ariawati, Ria Ratna. Usaha Kecil dan Kesempatan Kerja. Jakarta: Fakultas Ekonomi UNIKOM, 2004.

Dipta, I. Wayan. Membangun Jaringan Usaha Bagi Usaha Kecil dan Menengah. Jakarta, 2004.

Dunn, Elizabeth et.al. Microfinance Clients in Lima, Peru: Baseline Report For AIMS Core Impact Assessment. AIMS Project - USAID, 1999.

Gunardi, Harry Seldadyo. Kredit Untuk Rakyat. Bandung: Akatiga, 1997. 
Dr KPHN Hoedhiono Kadarisman, PhD, Memperkuat Ekonomi Nasional Berbasis Usaha Kecil dan Menengah, Lembaga Humaniora beherjasama dengan Kelompok Independen Indonesia (KII) Cetakan Pertama April 2007.

Iwantono, Sutrisno. Pemikiran Tentang Arah Kebijakan Pemerintah Dalam Pengembangan Usaha Kecil dan Menengah. Jakarta, 2004.

Mudrajad Kuncoro, Phd, Strategi Bagaimana Meraih Keunggulan Kompetitif? Erlangga, 2006.

Michael P. Todaro. Ekonomi Untuk Negara Berkembang, Suatu Pengantar Tentang Prinsipprinsip, Masalah dan Kebijakan Pembangunan. Jakarta: PT Bumi Aksara, Oktober 2000.

Nurul Widyaningrum, Ratih Dewayanti, Erna Ermawati Chotim, Isono Sadoko. Pola-Pola Eksploitasi Terhadap Usaha Kecil. Bandung: Yayasan Akatiga, Desember 2003.

Pangabean, Riana. Membangun Paradigma Baru Dalam Mengembangkan UKM. Jakarta, 2004.

Taufiq, Muhammad. Strategi Pengembangan UKM Pada Era Otonomi Daerah dan Perdagangan Bebas. Jakarta, 2004.

\section{Jurnal}

Widodo, Sri. "Pengaruh Pemberian Kredit Modal Kerja Terhadap Penghasilan Petani Ikan." Jurnal Pendidikan. Universitas PGRI. Yogyakarta.(2008).

Adiningsih, S. "Regulasi dalam Revitalisasi Usaha Kecil dan Menengah di Indonesia." Jurnal Unikom (2002), http://jurnal.unikom.ac.id/vol4/art7.html, diakses tanggal 5 April 2015.

Winarni, Endang Sri. "Strategi Pengembangan Usaha Kecil Melalui Peningkatan Aksesibilitas Kredit Perbankan.” Jurnal Infokop. Vol. 29 (2006) 92-98. 